\title{
EVALUATING THE PERFORMANCE OF LEUCAENA ACCESSIONS FOR AGROFORESTRY IN SUB-HUMID ENVIRONMENT, SOUTHERN \\ TANZANIA
}

\author{
AE Majule \\ Institute of Resource Assessment (IRA), P.O Box 35097, Dar es Salaam, Tanzania
}

\begin{abstract}
The performance of Leucaena accessions on acid soils in eastern coast Tanzania for agroforestry was evaluated for three years. Plant tree parameters assessed were fodder yield and plant stem height, stem girth, the number of total branches and poles production. Also, Leucaena psyllid, a common pest threatening the plants was also counted. Soil parameters assessed were pH organic carbon, total nitrogen, exchangeable calcium and magnesium. Result showed significant difference in growth between Leucaena accessions. Leucaena leucocephal cv K8 and Leucaena diversifolia were able to grow fast reaching 4.7 and $3.3 \mathrm{~m}$ respectively within a period of three years. Leucaena diversifolia produced the highest amount of fodder yielding $(7.8 \mathrm{t} / \mathrm{ha})$ followed by Leucaena leucocephala $\mathrm{cv} K 8(4.9 \mathrm{t} / \mathrm{ha})$. The number of branches, poles per tree and stem girth also differed significantly $(P<0.05)$ so as poles. Infestation by Leucaena Pysllid was highest in Leucaena lecocephala followed by Leucaena esculanta. There was a remarkable increase on soil pH, OC\%, total N\%, available P and exchangeable Ca and Mg after incorporating leucaena pruning in the soil. Leucaena diversifolia and Leucaena lecocephala $\mathrm{cv} K 8$ were found to be more adapted and potential in improving soil fertility and are recommended for agroforestry development.
\end{abstract}

\section{INTRODUCTION}

In tropical countries, low input agroforestry technologies have many advantages apart from protection of environment in farming systems (Burley and von Colwitz 1994). Since agroforestry can incorporate diverse multipurpose tree/shrub species, the farming system therefore varies from place to place and when introducing tree/shrub species from one area to another, one should be aware of the differences between agro ecological zones (Heinemann et al. 1989). This is because there has been in some places a problem of adaptability of the newly introduced exotic multipurpose trees and shrubs and this has caused many species in different places to perform below the expected level (Kusekwa et al 1993). It is necessary therefore, for researchers have to evaluate the performance of the different multipurpose trees and shrubs (MPTS) under different agro ecological zones (Duguma and Tonye 1994, Duguma et al 1994). This evaluation must also consider locally available potential agroforestry shrubs and trees since they are locally adapted.

There are many different accessions of Leucaena and they perform differently under the various agroecological zones of the tropical countries (Pfeiffer 1990, Kang et al 1990, Mureith et al 1994). Bandara and Gunasena (1989) observed a variation in biomass production among accessions of Leucaena in Sri Lanka. In Usambara mountains of north eastern Tanzania, observations made by Pfeiffer (1990) during evaluation of five Leucaena accessions showed that Leucaena diversifolia produced more forage and wood than Leucaena leucocephala. Accessions Leucaena le ucocephala ex Peru, Leucaena leucocephala cv Cunninghum and Leucaena leucocephala Giant ex Korogwe were the three poorest, producing less fodder. The experiment was conducted under tropical humid environment. 
Various agricultural research institutes in Tanzania have been evaluating the performance of various MPTS including different Leucaena accessions for suitability and adaptability. The general objective for this research was to evaluate the performance of ten Leucaena accessions in the southern coastal region. Specifically, the study was aimed to recommend potential and highly adaptable Leucaena accessions for fodder, building poles and for soil fertility improvement.
DESCRIPTION OF THE STUDY AREA

The experiment was conducted at the Naliendele Agricultural Research Institute (NARI) in southern zone of Tanzania (Figure $1)$. The experimental site is located at $10^{\circ} 22^{\prime} \mathrm{S}, 40^{\circ} 11^{\prime} \mathrm{E}$ and at an altitude of $120 \mathrm{~m}$ above sea level. The area receives a mean annual rainfall of about $1160 \mathrm{~mm}$ (unimodal) which falls between November and April. According to World Resource Base (1988), soils of the experimental site are mainly derived from sand stones (Ferralic arenosol), acidic in nature with more than $80 \%$ sand, low in exchangeable bases and cation exchange capacity (Majule 1999).

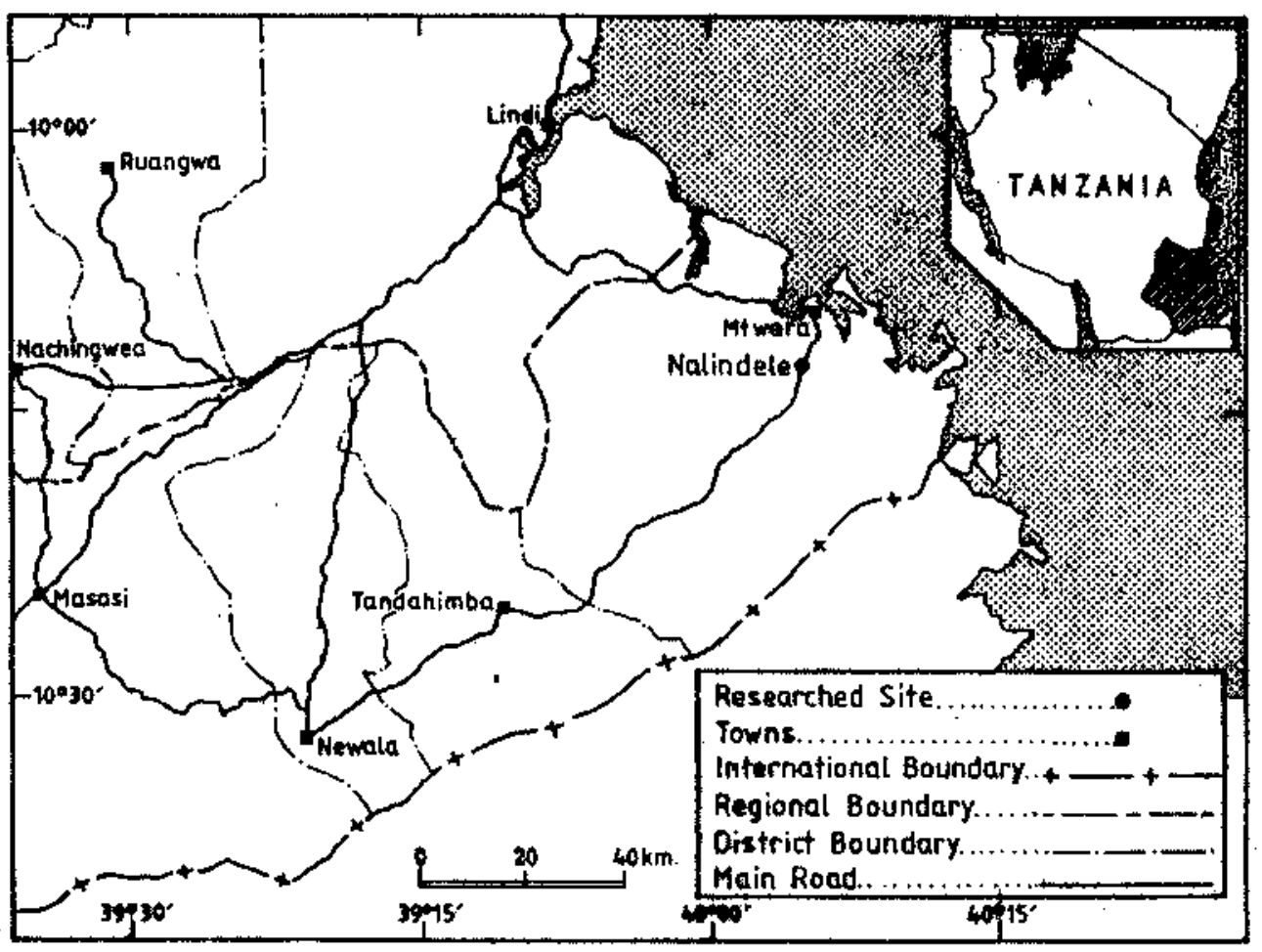

Figure 1: Location of experimental site at Naliendele Agricultural Research Institute (NARI).

Total nitrogen and available phosphorus are also very low. The fertility of newly opened field persists for only two cropping seasons and farmers must fallow the land for at least 
three seasons to maintain productivity. Chemical characteristics of the experimental

site are presented in Table 1.

Table 1: Selected soil chemical properties of the experimental site at Agricultural Research Institute, Naliendele Mtwara.

\begin{tabular}{cccccccccccc}
\hline \multirow{2}{*}{ Horizon } & Depth (cm) & OM\% & N\% & $\mathbf{p H}$ & $\mathbf{m g P} / \mathbf{k g}$ & \multicolumn{5}{c}{$\begin{array}{c}\text { Exchangeable Bases and CEC } \\
\text { (Cmol(+)/kg soil } \\
\text { Na }\end{array}$} & CEC \\
\hline \multirow{2}{*}{$\mathrm{Ap}$} & 0.30 & 0.54 & 0.04 & 5.5 & 2 & 0.46 & 0.16 & 0.10 & 0.02 & 1.2 \\
$\mathrm{Bw}$ & $30-50$ & 0.41 & 0.04 & 5.5 & 2 & 0.32 & 0.16 & 0.10 & 0.01 & 1.2 \\
\hline
\end{tabular}

\section{METHODS}

\section{Establishment of experimental plot}

Early in 199010 Leucaena accessions namely Leucaena leucocephala ex Peru, Leucaena leococephala cv K8, Leucaena esculenta 91309, Leucaena diversifolia, Leucaena leococephala Hawaiian Giant, Leucaena leucocephala ex Katumani, Leucaena leucocephala 58396, Leucaena leucocephala cv Cunninghum, Leucaena leucocephala 90790 and Leucaena leucocephala were introduced to the southern area of Tanzania for evaluation from the International Centre for Research on Agroforestry (ICRAF) in Kenya to Tumbi Agricultural Research Institute, western Tanzania. These materials were then distributed to the different agro ecological zones including the NARI for evaluation.

Before the wet season in the same year, seedlings were raised in a nursery for three months. A five-year fallow land was cleared, ploughed and harrowed to a fine bed. After this preparation the experiment was laid in a complete randomized block (CRB) with three replications. Plot size was $6 \times 6 \mathrm{~m}$, with three meter spacing between plots. In December 1991, seeds were raised in a nursery for a period of 12 months at NARI. In December 1992, seedlings were transplanted and planted in a hill at a spacing of $2 \times 2 \mathrm{~m}$ with a plant population per plot of 16 trees. All experimental plots were weeded and triple super phosphate was added at the rate of $100 \mathrm{~g}$ added per hill and covered with soil. Trees were left to grow for two seasons before pruning and data recording. Leucaena leucocephala in this case was considered to be a control due to its wide spread.

\section{Measurement of plant growth indicators} In January 1994 four central plants from each plot for all treatments were marked for data recording and pruned by cutting at a height of $1 \mathrm{~m}$ above the ground. Trees were then allowed to grow for five months. After that period in June 1994 data on stem height (m) and girth at $15 \mathrm{~cm}$ above the ground were recorded. Trees were again cut and pruned in order to determine fodder yield by taking all leaves and small plant twigs and weighing. This was repeated for the three seasons. In the same trial, the border trees were left to grow for the period of three years without cutting and pruning. These were used for recording data on pest population, number of branches and the number of straight poles available for building. In order to determine the effect of psyllid on trees, two fresh leaves from the four compass directions were taken per tree from each provenance. Four plants were used and all leaf materials were put in a polythene bags and taken to the laboratory for counting. This was done early in the morning for two days. 
Majule-Evaluating the perfomance of Leucaena accessions ...

\section{Assessment of soil fertility}

After the collection of plant performance data for a period of three years in 1997, leucaena accession plants were left to grow for a period of seven years until 2004 in order to allow regeneration of soil fertility through incorporation of leucaena accession pruning. Soil fertility assessment was achieved through soil sampling and analysis. Soil $\mathrm{pH}$ was determined in 1:2.5 soil:distilled water using a $\mathrm{pH}$ meter (Rowell 1994). Phosphorus (P) was extracted according to the Bray 1 method (Bray and Kurtz 1945) and the extracted P was determined colorimetrically after color development using the ascorbic acid method of Murphy and Riley (1962). Total nitrogen was determined by macro-Kjeldahl digestion followed by distillation (Bremner and
Mulvaney 1982). Organic carbon was determined by the Wakley-Black method (Nelson and Sommers 1982). Exchangeable $\mathrm{Ca}^{2+}$ and $\mathrm{Mg}^{2+}$ from the ammonium acetate leachate were determined by atomic absorption spectrophotometer (AAS).

\section{RESULTS AND DISCUSSION Leucaena plant growth and productivity Fodder yield}

Fodder yields in $\mathrm{t} \mathrm{ha}^{-1}$, maximum stem height $(\mathrm{m})$ after the last pruning for the three consecutive seasons is presented in Table 2. Generally, fodder yields increased across seasons for almost all accessions. As indicated in Table 2, the differences in performance of 10 Leucaena accessions in terms of fodder yield was not significant.

Table 2: $\quad$ Average fodder dry weight yields ( $\mathrm{t} / \mathrm{ha}$ ) of 10 Leucaena accessions over three consecutive seasons.

\begin{tabular}{lcccc}
\hline \multirow{2}{*}{ Accession } & \multicolumn{5}{c}{ Fodder yield ha/season } & Total yield \\
\cline { 2 - 5 } & $\mathbf{1 9 9 4}$ & $\mathbf{1 9 9 5}$ & $\mathbf{1 9 9 6}$ & \\
\hline & 2.7 & $1.5 \mathrm{c}$ & $1.4 \mathrm{f}$ & 5.60 \\
Leucaena leucocephala Ex Peru & 2.2 & $6.4 \mathrm{a}$ & $6.2 \mathrm{~b}$ & 14.80 \\
Leucaena leucocephala CV K8 & 2.8 & $2.0 \mathrm{c}$ & $2.2 \mathrm{c}$ & 07.00 \\
Leucaena esculenta 91309 & 4.4 & $6.0 \mathrm{ab}$ & $12.9 \mathrm{a}$ & 23.30 \\
Leucaena diversifolia & 2.0 & $1.6 \mathrm{c}$ & $2.2 \mathrm{e}$ & 05.80 \\
Leucaena leucocephala Giant ex Korogwe & 3.8 & $3.9 \mathrm{abc}$ & $4.0 \mathrm{~d}$ & 11.70 \\
Leucaena leucocephala Ex Katumani & 2.2 & $3.0 \mathrm{bc}$ & $4.9 \mathrm{c}$ & 10.10 \\
Leucaena leucocephala 90790 & 2.6 & $2.4 \mathrm{c}$ & $2.7 \mathrm{~d}$ & 07.70 \\
Leucaena leucocephala 58396 & 2.5 & $1.6 \mathrm{c}$ & $1.4 \mathrm{f}$ & 05.50 \\
Leucaena leucocephala cv Cunninghum & 3.4 & $3.1 \mathrm{bc}$ & $2.2 \mathrm{e}$ & 2.9 \\
Leucaena leucocephala (control) & 29.7 & 23 & 12 & \\
\hline CV\% &
\end{tabular}

NOTE: Within column means with the same letter are not significantly different.

The two accessions which produced more fodder than Leucaena leucocephala (control) during the first phase of data collection in 1994 were Leucaena diversifolia and Leucaena leucocephala ex Katumani with total fodder weights 4.4 and $3.8 \mathrm{t} /$ ha respectively (Table 2 ). After the first season, the following two seasons, Leucaena leucocephala cv K8 out yielded significantly $(\mathrm{P}<0.05)$ both Leucaena diversifolia and Leucaena leococephala ex
Katumani by producing $6.4 \mathrm{t} / \mathrm{ha}$ of fodder. In the third year, the highest fodder yield was reached by provenance Leucaena diversifolia $12.9 \mathrm{t} / \mathrm{ha}$ followed by Leucaena leucocephala cv K8 (6.2 t/ha).

The total dry weight yield of fodder for each accession after three seasons indicated that out of the ten accession the best three were Leucaena diversifolia, Leucaena leucocephala cv K8 and Leucaena 
leucocephala ex Katumani. This therefore suggests that these leucaena accessions can withstand semi humid environment and this therefore warrants their development for agroforestry.

\section{Plant stem height}

Data on tree height are presented in Table 3. Heights attained by different provenances was not significant different in the first and second seasons. Good performers were the Leucaena leucocephala cv K8, Leucaena diversifolia and Leucaena leucocephala ex Katumani. Accessions Leucaena leucocephala ex Peru and Leucaena leucocephala Giant ex Korogwe performed the worse (below control) in terms of stem height. It is interesting that the relative performances in terms of yields for fodder are similar to those for stem height.

Table 3: Average maximum trees stem height (m) of Leucaena accessions over period of three years.

\begin{tabular}{lcccc}
\hline \multirow{2}{*}{ Year } & \multicolumn{4}{c}{ Plant stem m/tree/season } \\
\cline { 2 - 5 } Accession & $\mathbf{1 9 9 4}$ & $\mathbf{1 9 9 5}$ & $\mathbf{1 9 9 6}$ & Mean \\
\hline Leucaena leucocephala Ex Peru & 1.1 & 1.6 & $1.8 \mathrm{~d}$ & 1.5 \\
Leucaena leucocephala CV K8 & 1.4 & 1.9 & $4.7 \mathrm{a}$ & 2.7 \\
Leucaena esculenta 91309 & 1.1 & 1.7 & $2.9 \mathrm{bc}$ & 1.9 \\
Leucaena diversifolia & 1.3 & 2.0 & $3.3 \mathrm{~b}$ & 2.2 \\
Leucaena leucocephala Giant ex Korogwe & 1.1 & 1.6 & $2.2 \mathrm{~cd}$ & 1.6 \\
Leucaena leucocephala Ex Katumani & 1.9 & 2.2 & $2.1 \mathrm{bc}$ & 2.1 \\
Leucaena leucocephala 90790 & 1.2 & 1.7 & $2.9 \mathrm{bcd}$ & 1.9 \\
Leucaena leucocephala 58396 & 1.2 & 2.0 & $2.5 \mathrm{bc}$ & 1.9 \\
Leucaena leucocephala Cv Cunnighum & 1.1 & 2.0 & $2.8 \mathrm{bc}$ & 2.0 \\
Leucaena leucocephala (control) & 1.2 & 1.9 & $2.2 \mathrm{~cd}$ & 1.8 \\
\hline CV\% & 32 & 16.4 & 17.2 & \\
\hline
\end{tabular}

NOTE: Within column means with the same letter are not significantly different.

\section{Leucaena branching and poles}

Table 4 summarizes the number of branches, straight poles, Psyllid distribution and girth per tree for the ten provenances assessed in the third season. None of the provenances differed significantly in the total number of branches they could produce. However significant differences $(\mathrm{P}<0.05)$ in straight poles among provenances were observed. Leucaena leucocephala K8 and Leucaena leucocephala giant ex Korogwe gave more poles available for building. Leucaena diversifolia gave few poles whereas Leucaena leucocephala ex Peru had only one pole.

\section{Plant stem girth}

Plant girth among accessions also differ significantly $(\mathrm{P}<0.05)$ among accessions (Table 4). Leucaena leucocephala K8, Leucaena leucocephala cv Cunninghum and Leucaena diversifolia performed better with plant girths of 20.6, 15.7 and $15.5 \mathrm{~cm}$ respectively. Accessions which performed poorly were Leucaena leucocephala Ex Peru, Leucaena leucocephala 58399 and Leucaena leucocephala ex Korogwe with plant girths of $13.8,13.6$ and $12.0 \mathrm{~cm}$ respectively. This observation further suggests the differences in growth ability of the ten accessions in the southern coastal areas. 
Majule - Evaluating the perfomance of Leucaena accessions ...

Table 4: $\quad$ Growth performance in terms of Branching, poles production and stem girth sizes

\begin{tabular}{lccc}
\hline & \multicolumn{3}{c}{ Growth parameter } \\
\cline { 2 - 4 } Accessions & No. of Branches & No. of Poles & $\begin{array}{c}\text { Stem girth } \\
\text { (cm) }\end{array}$ \\
\hline & 4 & $1 \mathrm{~d}$ & $13.8 \mathrm{~b}$ \\
Leucaena leucocephala Ex Peru & 7 & $5 \mathrm{a}$ & $20.6 \mathrm{a}$ \\
Leucaena leucocephala cv K8 & 4 & $2 \mathrm{~cd}$ & $14.5 \mathrm{~b}$ \\
Leucaena esculenta 91309 & 6 & $2 \mathrm{~cd}$ & $15.5 \mathrm{~b}$ \\
Leucaena diversifolia & 4 & $4 \mathrm{ab}$ & $12.0 \mathrm{~b}$ \\
Leucaena leucocephala Giant ex Korogwe & 5 & $2 \mathrm{~cd}$ & $14.3 \mathrm{~d}$ \\
Leucaenaleucocephala Ex Katumani & 6 & $3 \mathrm{ab}$ & $14.0 \mathrm{~b}$ \\
Leucaena leucocephala 90790 & 5 & $3 \mathrm{bc}$ & $13.6 . \mathrm{b}$ \\
Leucaena leucocephala 58396 & 4 & $4 \mathrm{bc}$ & $15.7 \mathrm{~b}$ \\
Leucaena leucocephala cv Cunninghum & 4 & $2 \mathrm{~cd}$ & $14.4 \mathrm{~b}$ \\
Leucaena leucocephala (control) & 25 & 46 & 34 \\
\hline CV\% & & & \\
\hline
\end{tabular}

Susceptibility of Leucaena accessions to pysllids pest

During the third year of evaluation (in 1996), pest infestation was observed to be common for most accessions and their distribution per plant are indicated in Fig. 2. More insects were found to affect Leucaena leucocephala, Leucaena esculanta 91309 and Leucaena leucocephala ex Peru. Less infested accessions were Leucaena leucocephala 58396, Leucaena diversifolia and Leucaena leucocephala cv $\mathrm{K} 8$ respectively. The resistance of Leucaena diversifolia to attack by pysllid has also been reported by Whealer and Brewbaker (1989).

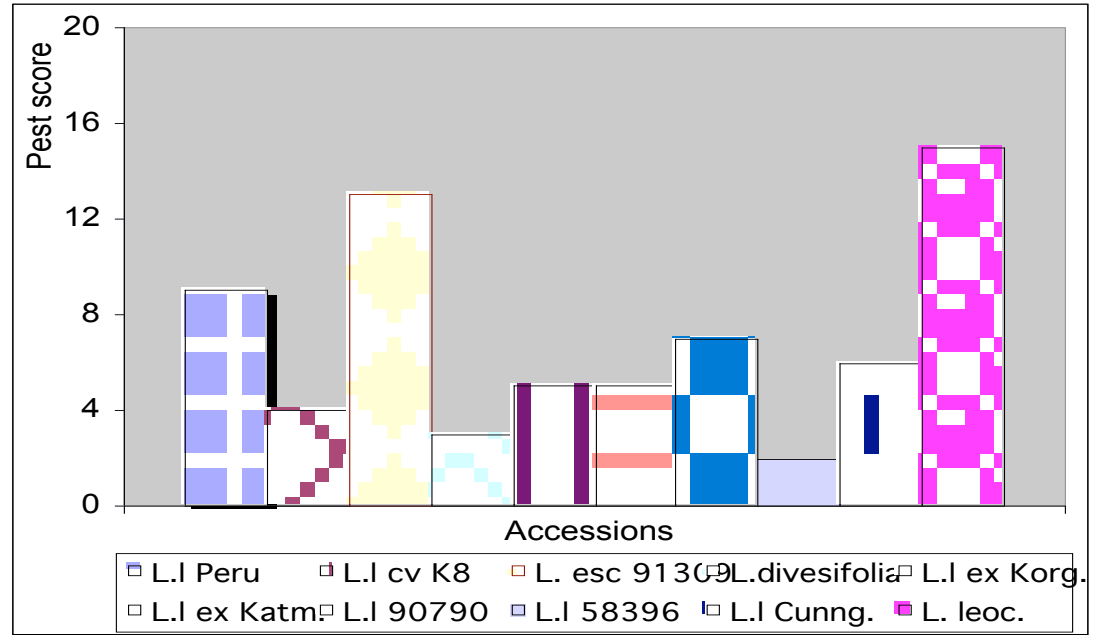

Figure 2: $\quad$ Pest counts in different Leucaena accessions 


\section{Long term effects on soil properties of adding leucaena accessions pruning to soil \\ Soil pH}

The effects of Leucaena accession pruning on soil chemical properties assessed after a period of 12 year is shown in Table 5. In general, there was a variable increase in soil $\mathrm{pH}$ values in most treatments by a maximum of 0.7 units with respect to $\mathrm{pH}$ value of the control in most plots under different accessions. Largest increase in soil
$\mathrm{pH}$ was measure in the soil from Leucaena diversifolia $(\mathrm{pH}$ 6.5) followed by Leucaena leucocephala $\mathrm{cv} \mathrm{K} 8(\mathrm{pH}$ 6.2) and then Leucaena leucocephala ex Katumani $(\mathrm{pH}$ 6.0 ). Soil $\mathrm{pH}$ in all other plots was above the original value of $\mathrm{pH} 5.5$ (Table 1) for the experimental site. This therefore suggests that the ameliorative potential of Leucaena accessions differs among accessions which therefore warrant a selection of potential species if $\mathrm{pH}$ improvement is the target.

Table 5: The impacts of Leucaena accession pruning on soil chemical properties

\begin{tabular}{|c|c|c|c|c|c|c|}
\hline \multirow[b]{3}{*}{ Accessions } & \multicolumn{6}{|c|}{ Soil chemical properties response } \\
\hline & \multirow[b]{2}{*}{$\mathrm{pH}$} & \multirow[b]{2}{*}{$\mathrm{OC} \%$} & \multirow[b]{2}{*}{ N\% } & \multirow[b]{2}{*}{$\mathrm{MgP} / \mathrm{kg}$} & \multicolumn{2}{|c|}{$\mathrm{Cmol}(+) / \mathrm{kg}$} \\
\hline & & & & & $\mathrm{Ca}$ & $\mathrm{Mg}$ \\
\hline Leucaene leucocephala Ex Peru & 5.80 & 0.64 & 0.09 & 5.10 & 1.24 & 0.09 \\
\hline Leucaena leucocephala cv K8 & 6.20 & 1.20 & 0.12 & 9.20 & 1.64 & 0.12 \\
\hline Leucaena esculenta 91309 & 5.80 & 0.68 & 0.08 & 6.00 & 1.26 & 0.80 \\
\hline Leucaena diversifolia & 6.50 & 1.36 & 0.16 & 9.90 & 1.78 & 0.16 \\
\hline \multicolumn{7}{|l|}{ Leucaena leucocephala Giant ex } \\
\hline Korogwe & 5.60 & 0.70 & 0.16 & 3.60 & 0.84 & 0.90 \\
\hline \multicolumn{7}{|l|}{ Leucaena leucocephala Ex } \\
\hline Katumani & 6.00 & 0.89 & 0.09 & 7.40 & 1.30 & 0.08 \\
\hline Leucaena leucocephala 90790 & 5.90 & 0.92 & 0.08 & 7.60 & 1.27 & 0.09 \\
\hline Leucaena leucocephala 58396 & 5.70 & 0.47 & 0.07 & 6.50 & 1.28 & 0.07 \\
\hline \multicolumn{7}{|l|}{ Leucaena leucocephala $\mathrm{cv}$} \\
\hline Cunnighum & 5.50 & 0.60 & 0.06 & 4.80 & 1.06 & 0.06 \\
\hline Leucaenaleucocephala (control) & 5.80 & 0.81 & 0.08 & 6.20 & 1.29 & 0.08 \\
\hline
\end{tabular}

Similar studies with other residue sources have shown that if residues from plants are well managed, soil acidity can significantly be reduced to desirable values above 5.5 (see e.g. Majule 1999, Omollo 2003). Legumes have been reported to have high potential in ameliorating soil acidity due to release of soluble alkalinity which may be in the form of Ca, Ma or K hydroxides (Sakala 1998, Majule 1999) or through microbial decomposition of organically bound inorganic molecules containing $\mathrm{Ca}$ such as calcium oxalate (Pocknee and Sumner 1997). These are likely to be the processes which brought about decreased soil acidity.

\section{Long term effects on exchangeable Ca and $\mathrm{Mg}$}

Likewise with the case of soil $\mathrm{pH}$, exchangeable $\mathrm{Ca}$ and $\mathrm{Mg}$ increased variably across all plots (Table 5) under different accessions. On average, exchangeable $\mathrm{Ca}$ increased three fold whereas exchangeable $\mathrm{Mg}$ increased two fold compared to the original values indicated in Table 1. Highest increase of exchangeable $\mathrm{Ca}$ was observed in plots under Leucaena diversifolia followed by Leucaena leucocephala $\mathrm{cv} \mathrm{K} 8$ whereby increases were 1.32 and 1.18 units respectively (Table 5). The lowest amount of exchangeable $\mathrm{Ca}$ was measured in sub plots where Leucaena leucocephala giant ex 
Korogwe were planted. With the case of exchangeable $\mathrm{Mg}$, a similar pattern was followed.

Regarding the soil acidity ameliorative potential of Leucaena accession pruning observed in this study, a relationship between an increase in exchangeable basic cations particularly $\mathrm{Ca}$ and $\mathrm{Mg}$ and soil acidity can be established. An increase in soil $\mathrm{pH}$ was found to be positive correlated with and increase in the sum of exchangeable $\mathrm{Ca}$ and $\mathrm{Mg}$ as indicated in Figure 3 with $r^{2}$ value of 0.8881 .

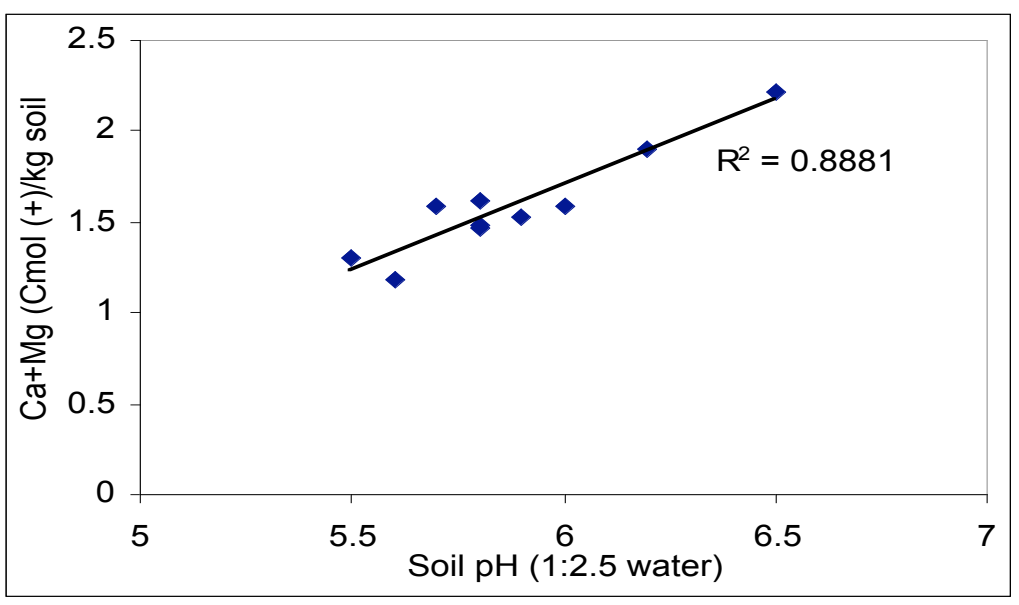

Figure 3: $\quad$ Relationship between $\mathrm{Ca}+\mathrm{Mg}$ and soil $\mathrm{pH}$ of in Leucaena plots.

The observed relationship (Fig. 3) is in broad agreement with proposed mechanisms involved in ameliorating soil acidity when organic residues are incorporated in the soil with releases of basic cations (Sakala 1998, Nkhalamba 1999, Majule 1999). In most cases, it has been shown that releases of $\mathrm{Ca}$, $\mathrm{Mg}$ and $\mathrm{K}$ occur from residue in soluble form or through microbial decomposition. Pocknee and Sumner (1997) have also shown that decomposition of $\mathrm{Ca}$ containing organic molecules such as calcium oxalate and calcium gluconate tends to release free $\mathrm{Ca}$ which then reacts with soil solution and increases soil $\mathrm{pH}$.

\section{Soil organic carbon and nitrogen}

Soil organic matter in the soil is a major source of plant nutrients which are released during mineralization process (Reus and Johnson 1986; Rowell 1994). Soil organic matter also improves soil physical conditions particularly soil structure, soil water holding capacity (Majule 1999) and soil workability. These properties are very important in enhancing and maintaining soil productivity. Experimental results show that incorporation of Leucaena accession pruning in the soil over years can significantly increase soil organic carbon (Table 5). This increase in soil organic carbon corresponds to an increase in soil total nitrogen in the Arenosol. An increase in both soil organic carbon and soil total nitrogen corresponds with biomass production by different leucaena accessions which is the highest with Leucaena diversifolia followed by Leucaena leucocephala cv K8.

Increase in soil organic carbon and nitrogen in Arenosol following additions organic residues additions is not surprising. Majule (1999) found that, long term additions (over five years) of maize residue, goat manure and cashew leaves residues increased soil organic carbon and total nitrogen remarkably 
with the addition of goat manure. Potential Leucaena accessions evaluated and recommended can therefore be developed further for agroforestry.

\section{Soil available phosphorus}

Phosphorus is one of the major limiting soil nutrients and it can significantly reduce crop yields if not constantly replaced in soils (Majule 1991). An assessment of the effects of Leucaena accessions on soil available P shows significant increases (Table 5) to levels more than the original $2 \mathrm{mg} / \mathrm{kg}$ soil (Table 1). An increase in the amount of soil available $\mathrm{P}$ was in the order Leucaena diversifolia $>$ Leucaena leucocephala $\mathrm{cv}$ K8>Leucaena leucocephala 90790. Other accessions are almost equally important in improving soil available P. Although soil available $P$ has increased because of incorporating leucaena pruning, the values are still on the low side $(<20 \mathrm{mgP} / \mathrm{kg}$ soil $)$ which is a critical concentration of most tropical soils (Landon 1991, URT 1993). However, the three Leucaena accessions which indicated high ability to improve major soil nutrient contents can be a very good source of nutrient cycling if planted on degraded soil.

\section{CONCLUSIONS}

Leucaena accessions performed differently in the semi humid environment of the southern eastern, Tanzania. The two best accessions to be developed for fodder production are the Leucaena diversifolia and Leucaena leucocephala $\mathrm{cv} \mathrm{K} 8$. The promotion of such species is very important in the area alongside with the small ruminant development project being implemented in the area. The same species are found to withstand pysllid infestation which is a serious pest in tropical environment. These species also have shown the ability to grow very fast in the area and if properly managed can conserve environment particularly soils. Farmers looking for building poles and firewood should plant Leucaena leucocephala ex Korogwe so as Leucaena leucocephala $\mathrm{cv} \mathrm{K8.} \mathrm{Its} \mathrm{is} \mathrm{therefore}$ recommended that strategies needs to be in place to ensure the production and distribution of recommended leucaena accessions in order to address livestock feed scarcity, building material shortage and improvement of soil fertility.

\section{ACKNOWLEDGEMENTS}

The author would like to thank the International Centre for Agroforestry (ICRAF) for financing this project. The Director of Naliendele Research Institute of Mtwara is also thanked for assisting in the management of experimental plots. Finally, I would like to thank the Director of the Institute of Resource Assessment (IRA) of the University of Dar es Salaam for allowing the researcher undertake this project and use of Institute facilities to process research data.

\section{REFERENCES}

Bandara MSPK and Gunasena HPM 1989 Performance of Some introduced nitrogen fixing trees in Sri Lanka. Nitr. Fix. Tree Res. Rep. 7: 30-33.

Bray RH and Kurtz LT 1945 Determination of total, organic and available forms of phosphorus in soils. Soil Science 59: 39 $-45$.

Bremner JM and Mulvaney CS 1982 Total nitrogen. In: Method of Soil Analysis Part 2. Agronomy Monograph No. 9. Page, A.L., Miller, R.H. and Keeney, P.R (eds). American Society of Agronomy Inc., Madison, Wisconsin. pp. 149 - 157.

Burley J and von Carlowitz PG 1994 Multipurpose Tree Germplasm. ICRAF/GTYZ, Nairobi, Kenya, 298 pp.

Duguma B, Tonye J, Kanmegne J, Manga T and Enoch T 1994 Growth of Ten multipurpose tree species on acid soils in Snagmelima, Cameroon. Agrofor. Syst. 27: 107-119.

Duguma B and Tonye J 1994 Screening of multipurpose trees and shrub species for agroforestry in the humid lowlands of Cameroon. For. Ecol. Mgmt 64: 2-3.

Heineman AM, Oteina HJO, Mengich EK and Amadallo B 1991 Growth and yield 
evaluation of twenty two provenances of eight multipurpose trees (MPT) for agroforestry uses in acid loam soil in Maseno in the bimodal highlands of Western Kenya. Paper presented at Regional Conference on Agroforestry Research and Development in Miombo Ecozone of Southern Africa. 16-22 June 1991, Lilongwe Malawi.

Kang BT, Reynolds L and Atta-Krah AN 1990 Alley Farm. Adv. Agron. 43: 315359.

Kusekwa ML and Dioniz NM 1993 The role of trees, shrubs and herbs in livestock production system in central Tanzania. Paper presented at National Agroforestry and Environment workshop, SUA, Morogoro, Tanzania, 12-16 October 1993.

Majule AE 1991 Response of maize to phosphorus application as banded and broadcasted Minjingu phosphate rock and triple super phosphate on Dystric Nitisol, Morogoro, Tanzania. BSc Dissertation, Sokoine University of Agriculture, Morogoro, Tanzania.

Majule AE 1999 The Effects of Organic Residues and Elemental Sulphur Additions to Soils of Southern Tanzania. Ph.D Thesis. Reading University.

Mureith JG, Thorpe J, Tayler RS and Reynolds L 1994 Evaluation of leucaena accessions for the semi-humid lowland tropics of East Africa. Trop. Agric. (Trinidad) 74: 83-87.

Murphy J and Riley JP 1962 A modified single solution method for determination of phosphate in natural water. Anal. Chem. Acta 27: 31 - 36.

Nelson DW and Sommers LW 1982 Organic carbon In: Method of Soil Analysis Part
2. Agronomy Monograph No. 9. Page, A.L., Miller, R.H. and Keeney, P.R. (eds) American Society of Agronomy Inc., Madison, Wisconsin. Pp. 561 573.

Nkhalamba JW 1999 The effect of incorporating crop residues on the development of surface charge in some Malawian acid soils. Ph.D Thesis, Reading University.

Pfeffer R 1990 Investigating possibilities of combining fodder production with erosion control and agroforestry in the West Usambara mountains of Tanzania. In Ecofarming practices of Tropical Small holdings (ed. Kotschi, J.) Tropical Agroforestry.

Pocknee S and Sumner ME 1997 Cation and nitrogen contents of organic matter determine its soil liming potential. Soil Sci. Soc. Amer. J. 61:86-92.

URT 1993 A guide for Soil Fertility Evaluation in Tanzania. National Soil Service. Mlingano Research Institute, Tanzania.

Reuss JO and Johnson DW 1986 Acid Deposition and the Acidification of Soils and waters. Ecological Studies 59:25-31. Springer-Verlag, New York.

Rowell DL 1994 Soil Science: Methods and Applications. Longman Scientific and Technical. London.

Sakala MG 1998 The Effect of Incorporating Plant Residues on Soil Acidity in The Management of Tropical Soils. Ph.D Thesis, Reading University,. 220pp.

Wheeler RA and Brewbaker JL 1989 Results from the International Leucaena Psyllid Trial Network. Leuc. Res. Rep. 30: 1115. 


\section{INSTRUCTIONS TO AUTHORS}

The Tanzania Journal of Science is published by the Faculty of Science, University of Dar es Salaam. Contributions on original work are accepted in the fields of pure and applied science as full research papers or notes (short communications). Comprehensive reviews and book reviews will be accepted at the discretion of the editor. Authors are requested to strictly follow the instructions below.

\section{Submission}

1.1 All papers should be submitted in triplicate hard copies and an electronic version must be included.

1.2 Submission of a paper implies that it has not been published previously, and is not simultaneously under consideration for publication elsewhere.

1.3 All editorial correspondence should be addressed to:

The Chief Editor, Tanzania Journal of Science, University of Dar es Salaam, P.O. Box 35065, Dar es Salaam, TANZANIA.

E-mail: TJS@Science.udsm.ac.tz

\section{Manuscript preparation}

2.1 Manuscripts must be typewritten, double spaced and with margins of at least $2.5 \mathrm{~cm}$ on the top and left side of the papers.

2.2 Use font Times New Roman 12

2.3 Limit your manuscripts to a maximum of 15 typed pages of A4 size including i l l u s t rations (e.g. photographs, diagrams, tables). The maximum length for short communications will be 6 typed pages

\section{Figures and tables}

3.1 Figures and tables should appear in numerical order and be described in the body of the text.

3.2 Originals of all figures should be in black ink and all lettering should be bold, readable, and big enough to allow reduction for final layout. Use $11 / 2 \mathrm{pt}$ line thickness for line drawings.

3.3 Figures, tables and other illustrations must be placed separately at the end of the paper. Indicate in pencil in the margins, recommended positions of figures, chemical schemes and tables in the text. An example of table layout is shown in Table 1.

3.4 Figure captions should be written on a separate sheet, but table titles should be typed on the same page as the table.

Table 1: Dimensions of text area to be used for Tanzania Journal of Science articles and of international and US paper sizes

\begin{tabular}{cccccc}
\hline & Text area & \multicolumn{2}{c}{ A4 paper } & \multicolumn{2}{c}{ US (Imperial) paper } \\
\cline { 3 - 6 } & $(\mathrm{mm})$ & $(\mathrm{mm})$ & $(\mathrm{in})$ & $(\mathrm{mm})$ & (in) \\
\hline Depth & 270 & 297 & 11.69 & 279.32 & 11.0 \\
Width & 185 & 210 & 8.27 & 215.84 & 8.5 \\
\hline
\end{tabular}

\section{Units}

4.1 The International System of Units (SI units) must be used throughout. Equivalent units e.g. pounds, miles, may be given in parentheses after the appropriate SI unit.

\section{Manuscript content}

Manuscripts should contain the following parts: 


\subsection{Title}

This must be short and precise. Abbreviation are not allowed. The title will be followed by the author(s) name(s), postal and E-mail addresses.

\subsection{Abstract}

This should be a brief summary of what was done, the main findings and the conclusions drawn. The abstract should not exceed 200 words. All papers, including short communications must have abstracts.

\subsection{Introduction}

This should contain a brief survey of the relevant literature and the objectives of the work.

\subsection{Materials and Methods}

Sufficient information should be given here, including relevant references, so that the study can be repeated by someone else.

\subsection{Results}

All illustrations must bear full captions, and must be specifically mentioned in the text, e.g. potassium ions enhanced stomata opening (Fig.5). The same data should not be presented both in the form of a graph and a table. Shorter tables and graphs should be combined to save space.

\subsection{Discussion}

This should emphasize the significance of the results and their relationship with other published work, and with the original objectives of the investigation. A brief concluding statement and recommendations for further work are normally given in the final paragraph.

The section on results and that on discussion may be combined to give one section on "results and discussion."

\subsection{Acknowledgements}

This should be very brief, about one to two sentences.

\subsection{References}

5.8.1 Citation in text

5.8.1.1 Use surname of author and year of publication: John (2000) or (John 2000).

5.8.1.2 Different references cited together should be in date order, for example: Mark 1970, Peter and Suleiman 1998, Green 2000).

5.8.1.3 If a paper has been accepted for publication but has not been published the term "(in press)" should be used instead of a date.

5.8.1.4 The abbreviation "et al." should be used in the text when there are more than two co-authors of a cited paper, for example: Maharage et al. (2001) or (Maharage et al. 2001).

5.8.2 List of references

5.8.2.1 References should be listed alphabetically at the end of the paper. Only the literature actually cited in the text should be listed here.

5.8.2.2 In the case of journals, authors' names followed by initials, the year of publication the title of the article, the name of the journal, the volume and the first and last pages of the article should be given in that order, for example:

a ) Playne MJ 1984 Increased digestibility of bagasse by pretreatment with alkali and steam explosion. Biotechnology Bioeng. 26:426-433.

b) Hecky RE, Mugidde R, Twongo T, Balirwa J and Mavuti K 2000 Ecosystem change in Lake Victoria. Tanzania J. Science 28: 50-61.

5.8.2.3 Book reference styles: a) standard, b) article in a book, c)thesis

a ) Schlegel HG 1988 General Microbiology. $6^{\text {th }}$ edn, Cambridge University Press, Cambridge.

b ) B oyton W V 1984 Cosmochemistry of the rare earth elements: Meteorite studies. In: Henderson P (ed) Rare earth element geochemistry Elsevier, Amsterdam.

c) Tamminen T 1990 Eutrophication and the Baltic sea: Studies on phytoplankton, bacterioplankton and 
pelagic nutrient cycles. $\mathrm{PhD}$ thesis,

Department of Environmental

Conservation, University of Helsinki. 